\title{
“Do my Roma and non-Roma patients need different care?" A brief step-by-step guideline for clinical practitioners
}

\author{
Andrej Belak $^{1,2,3,4}$ (D) Andrea Madarasova Geckova ${ }^{1,2,5} \cdot$ Jitse P. van Dijk ${ }^{2,3,5} \cdot$ Sijmen A. Reijneveld ${ }^{3}$
}

Received: 23 June 2018/Accepted: 26 April 2019/Published online: 21 May 2019

(c) The Author(s) 2019

\section{Introduction}

As researchers regularly publishing on Roma health in Slovakia and beyond, we often get approached by alerted clinical practitioners who treat Roma patients. Usually, they contact us with the impression that their Roma and their non-Roma patients have significantly different symptoms, morbidity or care outcomes and question how they could diversify and tailor their care accordingly. Fellow researchers elsewhere in Central and Eastern Europe (CEE) are likely to face similar requests for help (Cook et al. 2013; Crowe 2007).

Here, we offer a step-by-step guideline for further investigation and accommodation of such seeming differences. However, as the practitioners approaching us themselves most often suspect major genetic influences, we will start with brief reiterations of why genes are the least

Andrej Belak

andrej.belak@upjs.sk

Andrea Madarasova Geckova

andrea.geckova@upjs.sk

Jitse P. van Dijk

j.p.van.dijk@umcg.nl

Sijmen A. Reijneveld

S.A.Reijneveld@umcg.nl

1 Department of Health Psychology, Faculty of Medicine, P.J. Safarik University, Trieda SNP 1, 04011 Kosice, Slovakia

2 Graduate School Kosice Institute for Society and Health, Faculty of Medicine, P.J. Safarik University, Kosice, Slovakia

3 Department of Community and Occupational Medicine, University Medical Center Groningen, University of Groningen, Groningen, The Netherlands

4 Department of General Anthropology, Faculty of Humanities, Charles University, Prague, Czech Republic

5 Olomouc University Society and Health Institute, Palacky University Olomouc, Olomouc, Czech Republic and social determinants the most reasonable suspects to begin investigation with in this and in similar cases.

\section{Why should genes come last?}

To expect major genetic influences behind ethnic health disparities is unreasonable according to both the principles of population genetics and related evidence on social health disparities. Any population genetically more predisposed for a range of health problems should have been previously selected systematically, whether naturally or intentionally, for the unhealthy predispositions (Haydon 2007; Yudell et al. 2016). Such logically tense proposition seems highly unlikely also in the light of evidence on inter- and intragroup patterns in health status not corresponding to known patterns in genetic variability (Diez Roux 2012; WHO 2013; Yudell et al. 2016).

Accordingly, and alike for other ethnic health disparities (Diez Roux 2012; Dressler et al. 2005), the insignificance of genetic influences behind poor Roma health status has been confirmed empirically. The only genetic susceptibilities identified in Roma are higher frequencies of a handful of gene alleles causing rare diseases, peaking in some localities due to total social (reproductive) segregation from neighbouring populations (Diószegi et al. 2017; Fiatal et al. 2016; Kalaydjieva et al. 2001; Martinez-Cruz et al. 2016). Let us emphasize that this is despite a previous disproportionate focus of research specifically on possible genetic influences (Hajioff and McKee 2000; Zeman et al. 2003).

\section{Why should social determinants come first?}

According to epidemiological theory, social health disparities are almost always established and maintained socially. There are many other common ways for human bodies to get damaged beyond the above-discussed genetic 
susceptibilities to diseases, ranging from unfavourable material living conditions and risky health-related practices to stress. Health disparities between social groups are typically determined through socially maintained distinct combinations and the interplay of all such exposures over the life course (Diez Roux 2012; Krieger 2011; WHO 2010).

Like for other major ethnic health disparities (Bailey et al. 2017; Bhopal 2015; Dressler 2010), empirical evidence on CEE Roma health disparity fits the epidemiological theory well. Over the last ten years, research has shown that most of this disparity, too, can be explained by socially disadvantaged segments of the worse-off population disproportionately facing a wide range of environmental, behavioural, psychological and care-related exposures over the life course (e.g. Arora et al. 2016; Cook et al. 2013; EUC 2014; Geckova et al. 2014; Masseria et al. 2010).

Thus, any clinical discrepancies between Roma and non-Roma also most likely originate from, are maintained by, and can be alleviated via adjustments of social processes supporting unequal exposures over the life course. Different exposures can and do get embodied across ethnic divides; they then become biology (Bailey et al. 2017; Bhopal 2015; Gravlee 2009). However, as such differences only present the results of social differences, the tackling of their adverse clinical outcomes should start with assessing the underlying exposures, related social processes and their social root causes such as racism within and beyond healthcare (Feagin and Bennefield 2014; Phelan and Link 2015).

\section{Guideline}

Drawing on the above and related experience, we suggest the following approach (see also Fig. 1):

1. Are the seeming differences in outcomes real?

Do the studied differences remain statistically significant after adjustments for likely differences in the demographics of the different populations the compared patient groups are supposed to represent?

- Until this question can be answered "yes"; there is no need to consider tailoring treatment according the given Roma and non-Roma distinction criteria

2. Are the compared groups indeed Roma and nonRoma?

Do all patients in both groups agree to being labelled as such according to a set of unambiguous criteria? Ethnicity labelling can be constructed and contested in many ways by both those labelled and those labelling
(Janka et al. 2018; Ladányi and Szelényi 2001).

- If "no", drop the ethnic part of the hypothesis but continue with the next step (3).

- If "yes", specify the ethnic aspect of your hypothesis (e.g. What kind of Roma?) according to the identification criteria used and continue with the next step (3).

3. Do the patient groups differ in relevant living conditions?

Do available databases or follow-up communication with the patients indicate that the compared groups face living conditions that are distinct in aspects which might relate to the studied differences in outcomes?

- If "yes", continue with the investigation of possible causes related to living conditions (4).

- If "no", continue with the investigation of possible acquired biological causes (5).

4. Do the differences in relevant living conditions explain all the differences in outcomes?

Do all the studied differences in outcomes between the compared patient groups disappear after statistical adjustments for the differences in relevant aspects of the groups' living conditions?

- If "yes", try to develop and include among treatment options treatment plans that also account for the found influences of living conditions (e.g. Bourgois et al. 2017)

- If "no", continue with the investigation of possible acquired biological causes (5).

5. Do differences in relevant acquired biological traits explain the remaining outcome differences?

Does additional clinical testing show that the compared groups might have acquired different biological traits, which might relate to the studied outcomes?

- If "yes", try to develop and include among treatment options treatment plans that account for the found influences of acquired biological differences

- If "no", continue with the investigation of possible genetic causes (6).

6. Do differences in relevant genes explain the remaining outcome differences?

Does additional clinical testing show that the compared groups have genetic variants which might relate to the studied outcomes? 


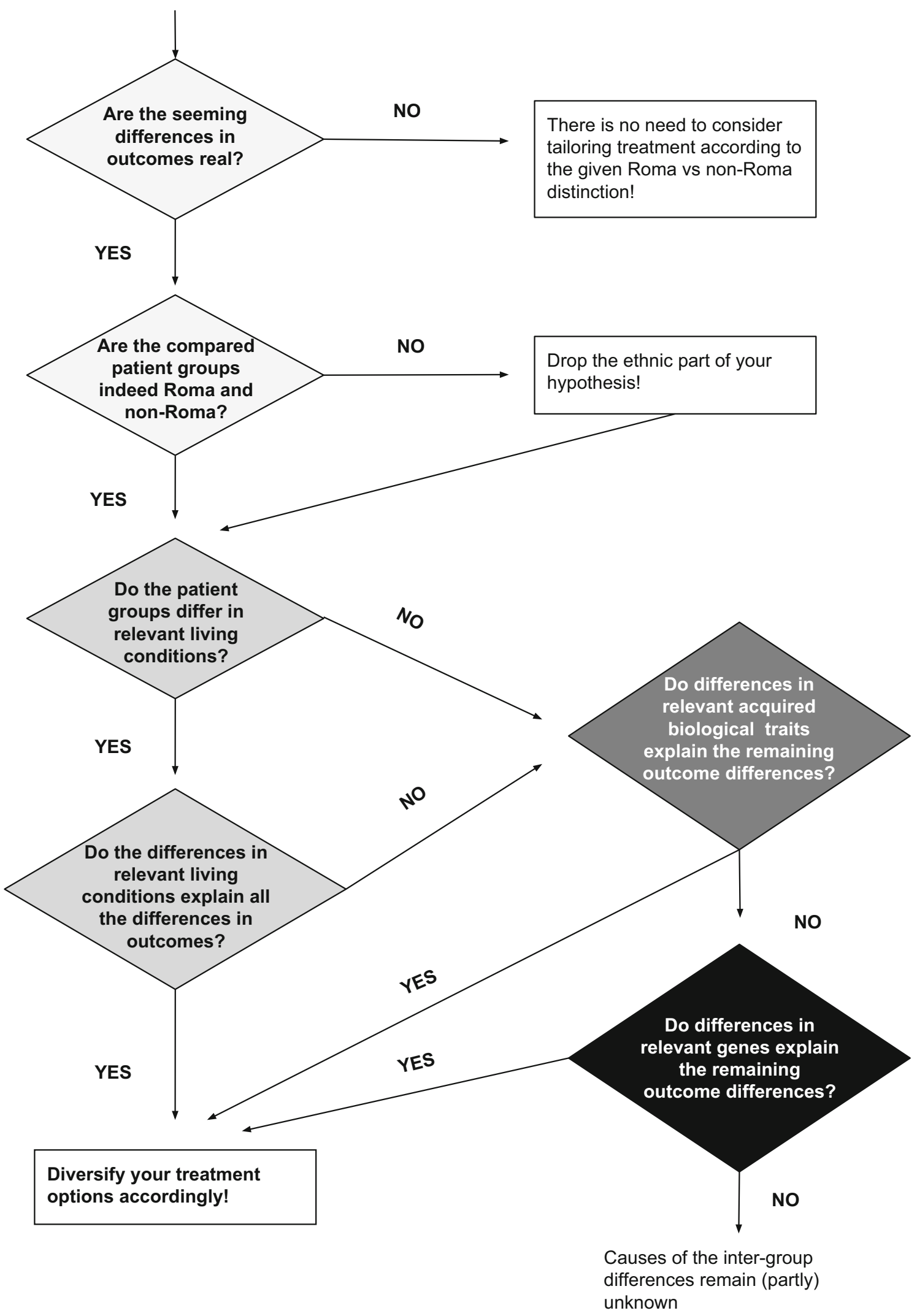

Fig. 1 A step-by-step guideline for dealing with apparent differences in Roma and non-Roma patients 
- If "yes", try to develop and include among treatment options treatment plans that account for the found influences of genes

- If "no", you were not able to identify some of the causes behind the existing differences.

\section{Conclusion}

We have herein proposed and justified a step-by-step guideline for dealing with apparent clinical differences in Roma and non-Roma patient groups. The guideline recommends that clinical practitioners facing such differences take a specific route. This route starts with assessing the statistical significance and representativeness of the difference through clarification and legitimization of ethnicity criteria, then goes on to assessment of differences in relevant living conditions and only arrives at assessing biological differences if refuting the preceding.

Acknowledgements Writing up of this work was financially supported by the Ministry of Education, Youth and Sports of the Czech Republic under Institutional Support for Long-term Development of Research Organizations 2012 at Charles University in Prague, Faculty of Humanities and by the Slovak Research and Development Support Agency under Contract No. APVV-15-0012.

\section{Compliance with ethical standards}

Conflict of interest The authors declare that they have no conflict of interest.

Open Access This article is distributed under the terms of the Creative Commons Attribution 4.0 International License (http://creative commons.org/licenses/by/4.0/), which permits unrestricted use, distribution, and reproduction in any medium, provided you give appropriate credit to the original author(s) and the source, provide a link to the Creative Commons license, and indicate if changes were made.

\section{References}

Arora VS, Kühlbrandt C, McKee M (2016) An examination of unmet health needs as perceived by Roma in Central and Eastern Europe. Eur J Public Health 26(5):737-742. https://doi.org/10. 1093/eurpub/ckw004

Bailey ZD, Krieger N, Agénor M et al (2017) Structural racism and health inequities in the USA: evidence and interventions. The Lancet 389(10077):1453-1463

Bhopal R (2015) Ethnicity, race, epidemiology, and public health. In: Tan CC, Gulliford M, Karim QA, Detels R (eds) Oxford textbook of global public health. Oxford University Press, Oxford

Bourgois P, Holmes SM, Sue K et al (2017) Structural vulnerability: operationalizing the concept to address health disparities in clinical care. Acad Med J Assoc Am Med Coll 92(3):299
Cook B, Wayne GF, Valentine A et al (2013) Revisiting the evidence on health and health care disparities among the Roma: a systematic review 2003-2012. Int J Public Health 58:885

Crowe D (2007) A history of the gypsies of Eastern Europe and Russia, 2nd edn. Palgrave/Macmilan, New York

Diez Roux AV (2012) Conceptual approaches to the study of health disparities. Annu Rev Public Health 33:41-58

Diószegi J, Fiatal S, Tóth R et al (2017) Distribution characteristics and combined effect of polymorphisms affecting alcohol consumption behaviour in the Hungarian general and roma populations. Alcohol Alcohol 52(1):104-111. https://doi.org/10. 1093/alcalc/agw052

Dressler WW (2010) Social inequality and health: a commentary. Med Anthropol Q 24(4):549-554

Dressler WW, Oths KS, Gravlee CC (2005) Race and ethnicity in public health research: Models to explain health disparities. Annu Rev Anthropol 34:231-252

EUC (2014) Roma Health Report. Health status of the Roma population. Data collection in the Member States of the European Union, p 153

Feagin J, Bennefield Z (2014) Systemic racism and U.S. Health care. Soc Sci Med 103:7-14. https://doi.org/10.1016/j.socscimed. 2013.09.006

Fiatal S, Tóth R, Moravcsik-Kornyicki Á et al (2016) High prevalence of smoking in the roma population seems to have no genetic background. Nicot Tob Res 18(12):2260-2267. https://doi.org/10.1093/ntr/ntw161

Geckova AM, Babinska I, Bobakova D et al (2014) Socioeconomic characteristics of the population living in Roma settlements and their association with health and health-related behaviour. Cent Eur J Public Health 22:S57-S64

Gravlee C (2009) How race becomes biology: embodiment of social inequality. Am J Phys Anthropol 139(1):47-57. https://doi.org/ 10.1002/ajpa.20983

Haydon J (2007) Genetics in practice: a clinical approach for healthcare practitioners. Wiley, Hoboken

Hajioff S, McKee M (2000) The health of the Roma people: a review of the published literature. J Epidemiol Community Health 54(11):864-9

Janka E, Vincze F, Ádány R et al (2018) Is the definition of Roma an important matter? The parallel application of self and external classification of ethnicity in a population-based health interview survey. Int J Environ Res Public Health 15(2):353

Kalaydjieva L, Gresham D, Calafell F (2001) Genetic studies of the Roma (Gypsies): a review. BMC Med Genet 2(1):5

Krieger N (2011) Epidemiology and the people's health: theory and context. Oxford University Press, New York

Ladányi J, Szelényi I (2001) The social construction of Roma ethnicity in Bulgaria, Romania and Hungary during market transition. Rev Sociol 7(2):79-89

Martinez-Cruz B, Mendizabal I, Harmant C et al (2016) Origins, admixture and founder lineages in European Roma. Eur J Hum Genet 24(6):937-943. https://doi.org/10.1038/ejhg.2015.201

Masseria C, Mladovsky P, Hernandez-Quevedo C (2010) The socioeconomic determinants of the health status of Roma in comparison with non-Roma in Bulgaria, Hungary and Romania. Eur J Public Health 20(5):549-554

Phelan JC, Link BG (2015) Is racism a fundamental cause of inequalities in health? Annu Rev Sociol 41:311-330

WHO (2010) A conceptual framework for action on the social determinants of health discussion paper series on social determinants of health, 2. World Health Organization, Geneva

WHO (2013) Review of social determinants and the health divide in the WHO European Region: final report. WHO Regional Office for Europe, Copenhagen, p 188 
Yudell M, Roberts D, DeSalle R et al (2016) Taking race out of human genetics. Science 351(6273):564-565. https://doi.org/10. 1126/science.aac4951

Zeman CL, Depken DE, Senchina DS (2003) Roma health issues: a review of the literature and discussion. Ethn Health 8(3):223-49
Publisher's Note Springer Nature remains neutral with regard to jurisdictional claims in published maps and institutional affiliations. 